\title{
Poisonous books: analyses of four sixteenth and seventeenth century book bindings covered with arsenic rich green paint
}

\author{
Thomas Delbey ${ }^{1}$, Jakob Povl Holck², Bjarke Jørgensen ${ }^{3}$, Alexandra Alvis ${ }^{4}$, Vanessa Haight Smith \\ Gwénaëlle M. Kavich ${ }^{6}$, Kimberly A. Harmon ${ }^{7}$, Bertil Fabricius Dorch ${ }^{2}$ and Kaare Lund Rasmussen ${ }^{1 *} \mathbb{D}$
}

\begin{abstract}
Efforts to read medieval manuscript waste recycled as bookbinding material in the sixteenth and seventeenth centuries have resulted in the chemical analysis of four books housed at the University Library of Southern Denmark and the Smithsonian Libraries in Washington DC. Four green coloured book bindings have been investigated by optical microscopy, micro X-ray fluorescence, X-ray diffraction, Raman spectroscopy, mass spectroscopy, and laser ablation inductively coupled plasma mass spectrometry. The results show that the green pigments used to obscure the manuscript waste in all four cases contain orpiment $\left(\mathrm{As}_{2} \mathrm{~S}_{3}\right)$ and indigo $\left(\mathrm{C}_{16} \mathrm{H}_{11} \mathrm{~N}_{2} \mathrm{O}_{2}\right)$. Although the books were printed in diverse places in Europe-Basel, Bologna, and Lübeck — the styles of their bindings indicate that they were likely bound in the same region in the same period. It is further likely that they acquired their arsenic-rich paint as part of the bookbinding process. Issues concerning the toxicity, health issues for library staff, conservators and researchers handling the books are also addressed.
\end{abstract}

Keywords: Rare books, Arsenic, Bookbinding, Handling of hazardous material, MS, LA-ICP-MS, $\mu X R F$, XRD, Raman, Book conservation

\section{Introduction}

Initially, three sixteenth and seventeenth century books were identified in the Herlufsholm Special Collection of the University Library of Southern Denmark, the bindings of which were partly decorated with green paint found to contain arsenic. This was reported in Denmark [1] and projected to the public, internationally, via The Conversation [2]. The matter received considerable public attention due to the apparent resemblance of the three green books to the deadly book of Aristotle that plays a vital part in the plot of Umberto Eco's 1980 novel The Name of the Rose. This media coverage precipitated the discovery of another book of the same period, also with green paint at the Smithsonian Libraries in Washington

\footnotetext{
*Correspondence: klr@sdu.dk

${ }^{1}$ Cultural Heritage and Archaeometric Research Team (CHART), Department of Physics, Chemistry and Pharmacy, University of Southern Denmark, Campusvej 55, 5230 Odense M, Denmark

Full list of author information is available at the end of the article
}

DC, USA. It became clear very quickly using portable $\mathrm{X}$-ray fluorescence (XRF) that the latter also contained arsenic. Originally, relying only on $\mu$-XRF in Denmark it was speculated that the paint could perhaps be Emerald Green $\left(\mathrm{Cu}\left(\mathrm{CH}_{3} \mathrm{COO}\right)_{2} \cdot 3 \mathrm{Cu}\left(\mathrm{AsO}_{2}\right)_{2}\right)$, which the present work shows is not the case. This seems to be the first report on poisonous green book bindings in the scientific literature. The question of the nature of the green colour, its original purpose, its chemistry, the particular history of the physical objects, as well as issues related to the handling and keeping of the particular books - and of similar painted works-is of potential importance to academic and national libraries, archives, museums, collectors, as well as to historical chemistry and physics.

The results of the present work are contextualized with a brief discussion of the materials used to create the paint, as well as sixteenth and seventeenth century binding practice. Finally, this paper addresses what the University of Southern Denmark and the Smithsonian 
Libraries are doing to reduce the threat of poisoning to staff and researchers, and what this discovery of arsenical books means to other libraries who may hold similar collections items.

\section{The samples}

Four books have been identified as having arsenic rich paint applied to the book bindings. Three are from University of Southern Denmark University Library; one is from the Smithsonian Libraries in Washington DC, USA. Photographs of the book bindings, the title pages, and the sampling sites are shown in Fig. 1. Descriptions of the books are listed below.

\section{KLR-11920: Herlufsholm 768.6 (Fig. 1a)}

Titles (two works bound together):

1. Historia Boiemica. A CL. V. Thoma Iordano Medico nouis Genealogiarum, Episcoporum, Regum, Ducum Catalogis, necessariis, quinètiam Annotationibvs sic ornata \& illustrata, vt nunc demùm edita dici possit.

2. De Bohemorum, et ex his Imperatorum Aliquot origine ac gestis historia.

Authors:

1. Johannes Dubravius (1486-1553).

2. Aeneas Silvius (Pope Pius II) (1405-1464).

Publisher: Pietro Perna (1519-1582), Basel.

Year of publication: 1575 .

Book block size in cm (height, width, depth): $31.5 \times 20 \times 3$.

Binding: Contemporary sixteenth century blind-tooled alum-tawed half-pigskin with a palmette frieze border. Blind-tooled (rolled) biblical motifs and texts in two centred columns, encased by blind-tooled lines. Seven raised spine bands. Head, foredge and tail in red. The texts: (1) ECCE AGNVS DEI, QUI TOLL (-is peccata mundi, miserere nobis)-John 1:29: Behold the Lamb of God that taketh away the sin of the world. (2) ECCE VIRGO CONCIPIET-Isaiah 7:14: Behold a virgin shall conceive. (3) HIC EST FILIVS MEVS DILECT (-us)-2 Pt 1:17-18: This is my son, the beloved. (4) (O) MORS ERO MORS TVA MORSVS-Hosea 13:14: O Death, I will be thy death $[3,4]$. Heavy wear on the biblical motifs and texts. On top of the front cover, the blind-tooled letters $\mathrm{H}$. H. D.(?) Bottom: the year 1581. Green pigment on parchment fragments (front and back cover), obscuring medieval text (unidentified). Blind-tooled diamond pattern in rolled lines on parchment fragments.
Provenance (modern labels of ownership excluded):

- Handwritten signature on front cover inside: Innreiterßheim (most likely a German surname, derived from a place name). MP (per manum propriam?). Possibly late seventeenth century.

\section{KLR-11971: Herlufsholm 775.2 (Fig. 1b)}

Title: Anglica Historia Libri Vigintiseptem. Ab ipso autore postremùm iam recogniti, ádq[ue]; amussim, salua tamen historiæ veritate, expoliti. Indices rerum singularum et vtiles et copoisos, in operīs calce adiectos reperies. Simon Grynaevs Lectori. [...]

Author: Polydore Vergil of Urbino (c. 1470-1555).

Publisher: Thomas Guarin (1529-1592), Basel.

Year of publication: 1570 .

Book block size in cm (height, width, depth): $34 \times 21 \times 5$.

Binding: Contemporary sixteenth century blind-tooled alum-tawed half-pigskin with a palmette frieze centre column (rolled), flanked by blind-tooled (rolled) biblical motifs and texts in two columns, encased by blind-tooled lines. Seven raised spine bands. The texts: (1) APPARVIT BENIGNI D-Epistle of St Paul to Titus 3:4: But when the goodness and kindness of God our Saviour appeared.

(2) ECCE AGNUS DEI-John 1:29: Behold the Lamb of God that taketh away the sin of the world. 3) DATA EST MICHI OM [nis potesta in calo]-Matthew 28:18: All authority in heaven and on earth has been given to me.4) DE FRVCTV VENT (-ris: VENT is rolled with a reversed N) - Psalm 131:11: The Lord hath sworn truth to David, and he will not make it void: of the fruit of thy womb I will set upon thy throne [3, 4]. Green pigment on parchment fragments, obscuring medieval text (front cover: Corpus Iuris Canonici, De rescriptis, Sexti Decret. Lib. I. Tit. III. Cap. XII-XIV. Back cover: Corpus Iuris Civilis (Justinian), Feudorum Lib. I, Tit. IX-XIII.). Blind-tooled lines on parchment fragments (front and back cover).

Provenance (modern labels of ownership excluded):

- Latin inscription on title leaf, bottom, sixteenth century.

R. V. D. M. Valentino Schachtio fratri, in(?) Ch. Ani. ddt Henricus Schinkius.

Heinrich Schinke (died 1593) was second vicar in Güstrow, Mecklenburg $[5,6]$. Valentin Schacht 

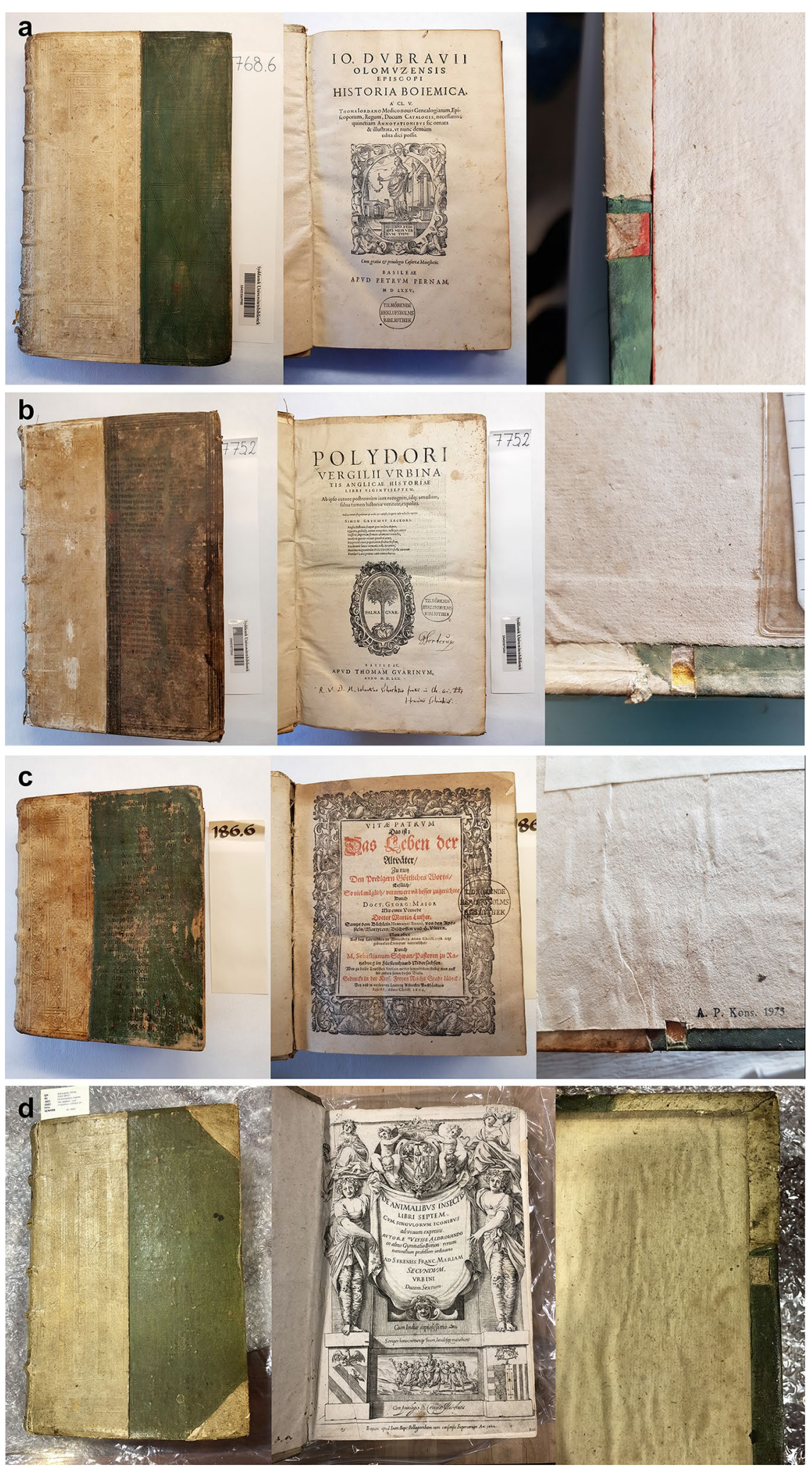

Fig. 1 a KLR-11920/Herlufsholm 768.6. exterior, frontispiece, and sampling site; b KLR-11971/Herlufsholm 775.2. exterior, frontispiece, and sampling site; c KLR-11972/Herlufsholm 186.6. exterior, frontispiece, and sampling site; d KLR-12109/Smithsonian QH41.A43 1602. Exterior, frontispiece, and sampling site. All the samples extracted are ca $5 \times 5 \mathrm{~mm}$. The dimensions and other bibliographical details of the books are given in the text 
(1540-1607), was a professor of theology at the University of Rostock (est. 1419) [7], archdeacon/pastor at St. Jakobi in Rostock, rector of the University of Rostock $1570,1582,1588,1594$, and 1600. The abbreviation " $R$. V. D. M." could stand for" Rector Universitatis Dominus Magister". It would appear that the older Heinrich Schinke gave (lat. dedit) this book to his brother of the church, Valentin Schacht.

- Handwritten signature on title leaf.

\section{G. Sorterup.}

Possibly the Danish vicar, Jørgen Jørgensen Sorterup (1662-1723). Jørgen = Georg.

\section{KLR-11972: Herlufsholm 186.6 (Fig. 1C)}

Title: Vitæ Patrvm Das ist: Das Leben der Altväter/Zu Nutz Den Predigern Göttliches Worts/Erstlich/So viel müglich/vernewert vn besser zugerichtet [...] mit einer Vorrede Doctor Martin Luther. Sampt dem Büchlein Hermanni Bonni, von den Aposteln/Martyrern/Bischoffen vnd H. Vätern. Nun aber Auss dem Lateinischen zu Wittenberg Anno Christi 1578. letzt gedruckten Exemplar verteutschet/Durch M. Sebastianum Schwan/Pastoren zu Ratzeburg im Fürstenthumb Nidersachsen. [...]

Author: Georg Major (1502-1574).

Publisher: Laurentz (Lauritz) Albrecht (deceased before 1605), Lübeck.

Year of publication: 1604 .

Book block size in $\mathrm{cm}$ (height, width, depth): $19 \times 15.5 \times 5$.

Binding: Early seventeenth century blind-tooled alumtawed half-pigskin with rolled flowers and intertwining leaves and diamond shaped figures, encased by blindtooled lines. Six raised spine bands. Medieval manuscript fragments on the front and back cover. Green pigment on parchment fragments, obscuring medieval text (parts of Sancti Gregorii Homiliarum in Ezechielem, Liber I, Homilia X i.a.). Blind-tooled lines on parchment fragments.

Provenance (modern labels of ownership excluded):

- Handwritten signature on end sheet prior to title leaf.

Hedewig: Von: Allefeldt.

This previous owner is most likely of the noble family line Ahlefeldt with numerous members in Schleswig-Holstein and Denmark. Several women go by the name of Hedevig or Hedvig.

\section{KLR-12109: Smithsonian QH41.A43 1602 Barcode 39088002066793 (Fig. 1d)}

Title: De animalibus insectis libri septem: cum singulorum iconibus ad viuum expressis autore Vlysse Aldrovando in almo Gymnalio Bonon, rerum naturalium professore ordinario, ad sereniss, Franc. Mariam, secundum, vrbini, ducem sextum: cum indice copiosissimo.

Author: Ulisse Aldrovandi.

Publisher: Bapt. Bellagambam, Bologna.

Year of Publication: 1602.

Book block size in cm (height, width, depth): $35 \times 23 \times 5.6$

Binding: Contemporary three-quarters binding of blindtooled pigskin with acanthus leaves and classical busts and green-stained manuscript waste. Five raised bands. Title in ink on spine. Pigskin corner on lower back board absent, displaying unstained manuscript waste. The text of the manuscript waste is as-yet unidentified.

Provenance:

- Unfortunately, not much is known about how or when this book came into the collection of the Smithsonian Libraries. The presence of a blind-embossed "Smithsonian Institution National Museum" stamp indicates that the book was in the collection prior to the opening of the Natural History Museum in 1911.

- There are a few other small annotations on the front and rear pastedowns that appear to indicate a contemporary shelfmark.

\section{Analytical methods}

\section{Sample mounting and use}

Samples of ca. $5 \times 5 \mathrm{~mm}$ were procured by cutting with a scalpel from the inside of the bookbindings. The sample size was considered necessary in order to perform the array of analytical techniques described below, the large sample size mainly due to have sufficient area for XRD. A ca. $5 \times 2 \mathrm{~mm}$ piece was cut of each sample and embedded edge-up in Struers Epofix Resin. The embedded sample was ground on a Struers LaboForce 100 grinding and polishing machine using 500 and $1200 \mathrm{SiC}$ abrasive foils, followed by diamond polishing with 9,3 , and $1 \mu \mathrm{m}$ diamond paste.

\section{Optical microscopy}

Optical images were recorded in polarized light using a Zeiss Axioscope microscope equipped with an Axiocam 105 Color camera. 


\section{Laser ablation inductively coupled plasma mass spectrometry (LA-ICP-MS)}

Laser ablation (LA) was performed with a CETAC LXS213 G2 equipped with a NdYAG laser operating at the fifth harmonics at a wavelength of $213 \mathrm{~nm}$. A $10 \mu \mathrm{m}$ circular aperture was used. The shot frequency was $20 \mathrm{~Hz}$. The scans were performed with a scan speed of $10 \mu \mathrm{m} / \mathrm{s}$. The helium flow was $600 \mathrm{~mL} / \mathrm{min}$. The laser operations were controlled by the DigiLaz G2 software provided by CETAC [8].

Inductively coupled plasma mass spectrometry (ICPMS) analyses were carried out using a Bruker Aurora M90 equipped with a frequency matching RF-generator. The basic parameters were as follows: radiofrequency power $1.30 \mathrm{~kW}$; plasma argon gas flow rate $16.5 \mathrm{~L} / \mathrm{min}$; auxiliary gas flow rate $1.65 \mathrm{~L} / \mathrm{min}$; sheath gas flow rate $0.18 \mathrm{~L} / \mathrm{min}$. The following isotopes were measured all without skimmer gas: Na23, Mg24, Al27, Ca44, Fe57, Cu65, As75, Rb85, Sr88, Ag107, Sb121, Ba137, Au197, $\mathrm{Hg} 202$ and Pb208. The analysis mode used was peak hopping with 3 points per peak, and the dwell time was $1 \mathrm{~ms}$ for $\mathrm{Na} 23, \mathrm{Ca} 44, \mathrm{Mn} 55$ and Fe57, and $10 \mathrm{~ms}$ for the rest of the analysed isotopes. The total scan time for all the selected isotopes was approximately $280 \mathrm{~ms}$.

LA-ICP-MS analyses were performed on the Epoxy embedded samples.

\section{$\mu$-X-ray fluorescence spectrometry ( $\mu$-XRF)}

An ARTAX-800 $\mu$-XRF manufactured by Bruker-Nano was used for the $\mu$-XRF measurements. The beam diameter was between 60 and $64 \mu \mathrm{m}$ in diameter. A high tension of $50 \mathrm{kV}$ and a current of $600 \mu \mathrm{A}$ were used. For each sample, 200 scans were measured with a 30 s live time under a constant He flow of $1 \mathrm{~mL} / \mathrm{min}$. The penetration of $50 \mathrm{keV} \mathrm{X}$-rays is several $\mu \mathrm{m}$ and based on absorption calculations for the outgoing low energy X-rays (NIST$\mathrm{XCOM}$ ) it can be seen, that the analyses reflect a layer of approximately 1-20 $\mu \mathrm{m}$ thickness depending on the chemistry of the outermost layer.

Absolute calibration of the concentrations has been performed by the DCCR-method (Direct Calibration from Count Rates) provided by the Bruker software using the standard reference material NIST-2711. For the determination of S, a NIST-610 standard was used with the assumed $S$ concentration value of $570 \pm 70 \mu \mathrm{g} / \mathrm{g}$ [9]. The quantitative results can only be considered semiquantitative because of the difference between the matrix of the samples (paint layer on parchment) and the matrix of the standard materials (glass for NIST-610 and pressed pellet from NIST-2711).

The $\mu$-XRF measurements were performed perpendicular to surface area of the cut samples from the four books.

\section{$X$-ray diffraction (XRD)}

The analysis was performed using a PANalytical X'Pert PRO MPD system (PW3050/60) diffractometer with $\mathrm{Cu}$ $K \alpha$ radiation as the source $(\lambda=1.54 \AA)$ and a PIXcel3D detector. The $\mathrm{X}$-ray generator was set to an acceleration voltage of $45 \mathrm{kV}$ and a filament emission to $40 \mathrm{~mA}$. The samples have been placed in a sample-holder and was sealed between two sheets of Kapton polyimide foil. All measurements were performed with a $2 \Theta$ angle step size of $0.013^{\circ}$ and a counting time of $1500 \mathrm{~s}$ per step in a range from $5^{\circ}$ to $75^{\circ} 2 \Theta$. An empty sample holder with the Kapton polyimide foil was also measured in the same conditions in order to subtract the background caused by the foil. Data were collected using X'Pert Data Collector. The qualitative analysis was performed using Highscore Plus software and Crystal Impact Match software linked to the ICDD PDF-2 database. The semi-quantitative results have been measured using the reference intensity ratio method (RIR).

The XRD measurements were performed on the painted surface of the cut out samples.

\section{Raman spectroscopy}

Raman measurements were conducted using a Thermo Scientific DXR Raman microscope equipped with a $633 \mathrm{~nm}$ laser and a $10 \times$ objective. The laser power was $3 \mathrm{~mW}$, the spectral resolution was $5 \mathrm{~cm}^{-1}$ at full width at half maximum (FWHM) and the spot size had a diameter of $2.1 \mu \mathrm{m}$.

The Raman spectroscopy was performed on the painted surfaces of the cut out samples.

\section{Mass spectrometry}

A sample of surficial scrapings of less than $0.1 \mathrm{mg}$ of the green paint was dissolved in acetonitrile and a mass spectrum acquired on a Bruker micro TOF QII. The instrument was operated with electrospray ionization in positive mode. The capillary voltage was set to $-4200 \mathrm{~V}$.

\section{Air samples}

At the Smithsonian Libraries, air samples were collected for both arsenic and arsine to help determine exposure to library staff, and to provide information for developing appropriate storage and handling protocols. The air sampling was performed for only one of the four books in this study, the KLR-12109.

Two types of air samples were collected, personal exposure and ambient air. Air monitoring for personal exposure was performed on a Smithsonian Library staffer during the procurement of the book binding sample for this study. A laboratory chemical fume hood was used to control exposure during the book sampling. Ambient air 
samples were collected, subsequently, near the surfaces of the book while the book was unhandled and left inside the laboratory chemical fume hood, with the sash positioned down and the fan turned off, to produce "worstcase scenario" air concentrations. Air samples were also collected, at the same time, on another Smithsonian Libraries conserved book that had arsenic-containing edge staining. This book was handled, and pages were thumbed through by the staffer during the sampling. While this book was not part of this study, the results are included in this paper to provide additional information to the reader on potential exposure levels from other types of arsenic-containing books.

Personal exposure air monitoring samples for arsenic (inorganic) particulate and arsenic trioxide vapor were collected using calibrated air sampling pumps, connected via Tygon@ tubing to $37 \mathrm{~mm}$ mixed cellulose ester filter cassettes (MCEF) with treated backup pads, and positioned in the staffer's breathing zone (BZ) at collar level. Ambient air samples were similarly collected, with sampling cassettes positioned in close proximity to the book's surface. The air sampling pumps were calibrated at a flow rate of $3 \mathrm{~L}$ per minute. All samples, including field blanks, were analyzed for arsenic using OSHA Method ID105 M (ICP-MS) by Analytics Corporation, an accredited industrial hygiene laboratory.

Personal exposure air monitoring samples for arsine were collected using calibrated air sampling pumps, connected via Tygon@ tubing to charcoal sampling tubes, and positioned in the worker's BZ at collar level. Ambient air samples were similarly collected, with sampling tubes positioned in close proximity to the book's surface. The air sampling pumps were calibrated at a flow rate of $0.2 \mathrm{~L}$ per minute. All samples, including field blanks, were analyzed for arsine using NIOSH Method $6001 \mathrm{M}$ by Analytics Corporation, an accredited industrial hygiene laboratory.

Arsenic exposure air monitoring results were compared with the OSHA Permissible Exposure Limit (PEL) of 0.01 milligrams per cubic meter of air $\left(\mathrm{mg} / \mathrm{m}^{3}\right)$ and the action level of $0.005 \mathrm{mg} / \mathrm{m}^{3}$, which is used to determine the need for inclusion in an occupational medical surveillance program. Arsine results were compared with the OSHA PEL of 0.05 parts per million parts air (ppm) and the action level of $0.025 \mathrm{ppm}$. All OSHA PELs and action levels are calculated as 8 -h time-weighted average (TWA) exposure concentrations.

The exposure air monitoring results were also compared to the non-regulatory exposure limits recommended by ACGIH and NIOSH. ACGIH and NIOSH limits are considered best practice, "health-based" exposure limits that nearly all workers may be repeatedly exposed to without adverse health effects, based on the available scientific information. The ACGIH Threshold Limit Value (TLV) for arsenic is the same as the OSHA PEL. The ACGIH TLV for arsine is $0.005 \mathrm{ppm}$. The NIOSH Recommended Exposure Limit (REL) for arsenic is $0.002 \mathrm{mg} / \mathrm{m}^{3}$ for a 15 -min exposure, and the REL for arsine is $0.0006 \mathrm{ppm}$, also for a 15 -min exposure.

\section{Wipe samples}

At the Smithsonian Libraries, surface wipe samples were also collected for arsenic to assess surface contamination, which could pose an arsenic exposure hazard to staff, in addition to handling the books themselves. Detectable arsenic concentrations on wipe samples indicate contamination on surfaces contacted by the book, which would need to be addressed by handling and storage protocols The wipe sampling was performed for only one of the four books in this study, the KLR-12109.

The arsenic wipe samples were collected, using a Ghost Wipe kit, from the blotter paper placed under the book in the laboratory chemical fume hood, and from gloved hand surfaces of the Smithsonian Library staffer after the book was handled and the binding sample procured for this study. The samples were collected using NIOSH 9102 protocol. The samples were analyzed using NIOSH 7082 M/7300 by Analytics Corporation, an accredited industrial hygiene laboratory. Wipe samples were also collected, at the same time, on the other Smithsonian Libraries conserved book with the arsenic-containing edge staining. This book was handled, and pages were thumbed through by the staffer prior to the wipe sampling. While this book was not part of this study, the results are included in this paper to provide additional information to the reader on potential exposure levels from other types of arsenic-containing books.

The level of risk posed by the arsenic concentrations reported on the wipe samples was assessed by comparing the concentrations to the "health-based" settled dust screening value for arsenic of $387 \mu \mathrm{g} / \mathrm{m}^{2}$, as OSHA, ACGIH, and NIOSH do not currently have regulatory/ recommended limits for surface wipes. The screening value, based on an assigned toxicity value for arsenic, was developed by the World Trade Center (WTC) Indoor Air Task Force Working Group to be protective of long-term habitability of residential buildings, post $9 / 11$, to evaluate potential inhalation and ingestion risk from surface contamination levels reported for various contaminates, including arsenic. This screening value is published in the "World Trade Center Indoor Environmental Assessment: Selecting Contaminants of Potential Concern and Setting HealthBased Benchmarks" (Mark A. Maddaloni et al. 2003, https://epa-prgs.ornl.gov/radionuclides/copc_bench mark.pdf) [10]. 


\section{Results}

\section{Microscopic observations}

The four microscope pictures taken in polarized light (Fig. 2) show that the four samples are different in appearance and in thickness of the applied green paint layer. KLR11920/Herlufsholm 768.6 has a paint layer which at places is thicker than $200 \mu \mathrm{m}$. The matrix is observed to be made of fine grains with light green or blue colour. Embedded in this matrix is seen several yellow coarser crystals, several flakes or fibres of the colour light olive green, and some white or translucent grains. On the sample KLR-11971/Herlufsholm 775.2, the green layer is thinner than $10 \mu \mathrm{m}$. Like KLR11920, yellow and translucid crystals can be seen, as well as the green-blue compound which appears non-crystalline. However, the fine-grained matrix is not visible on this sample. KLR-11972/Herlufsholm 186.6 has also a thin green paint layer in which yellow coarse crystals are embedded. KLR-12109/Smithsonian QH41.A43 1602 has a distinct and well-defined paint layer where coarse yellow crystals as well as translucent crystals are seen in a green/blue matrix. The differences in thickness probably only reflect that paint was applied in varying thicknesses.

\section{LA-ICP-MS}

The spatial distribution of 15 selected isotopes determined by LA-ICP-MS are shown in Fig. 3. At the top is shown an optical micrograph of the embedded sample taken in polarized light. The first column of elemental distribution plots consists of five elements which are considered non-colouring and non-toxic: $\mathrm{Na}, \mathrm{Mg}, \mathrm{Al}$, $\mathrm{Ca}$, and $\mathrm{Sr}$. The next two columns are the most interesting elements from the present perspective of colour and toxicity: $\mathrm{As}, \mathrm{Sb}, \mathrm{Cu}, \mathrm{Fe}, \mathrm{Ag}, \mathrm{Ba}, \mathrm{Au}, \mathrm{Hg}$, and $\mathrm{Pb}$. Rubidium cannot be considered toxic, but it is clearly co-varying with the arsenic containing paint, which is why it is placed here.
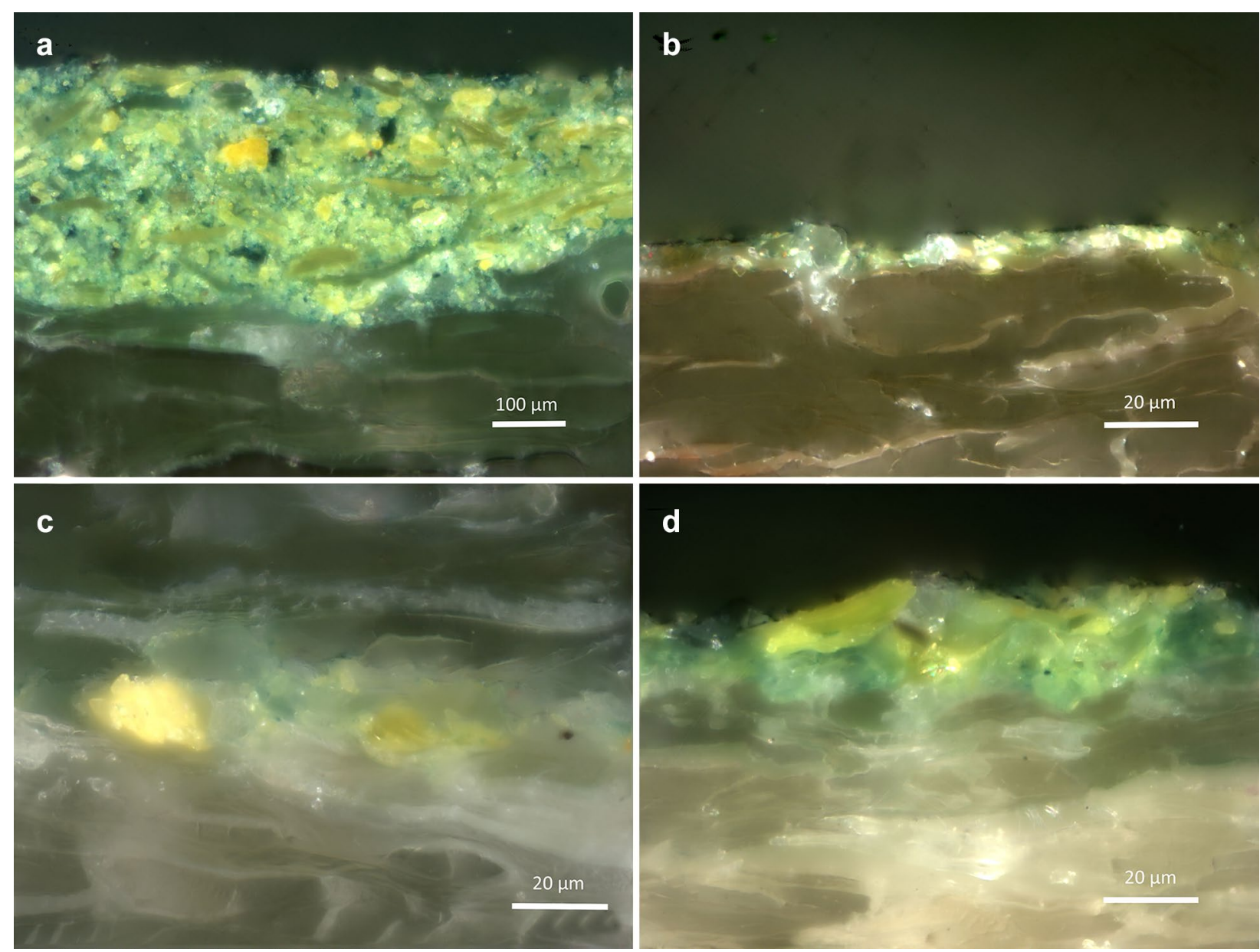

Fig. 2 Optical micro-photographs. a KLR-11920/Herlufsholm 768.6; b KLR-11971/Herlufsholm 775.2; c KLR-11972/Herlufsholm 186.6; d KLR-12109/ Smithsonian QH41.A43 1602. Due to the thickness of the samples, note the difference in scale bars for KLR-11920 and the rest of the samples 


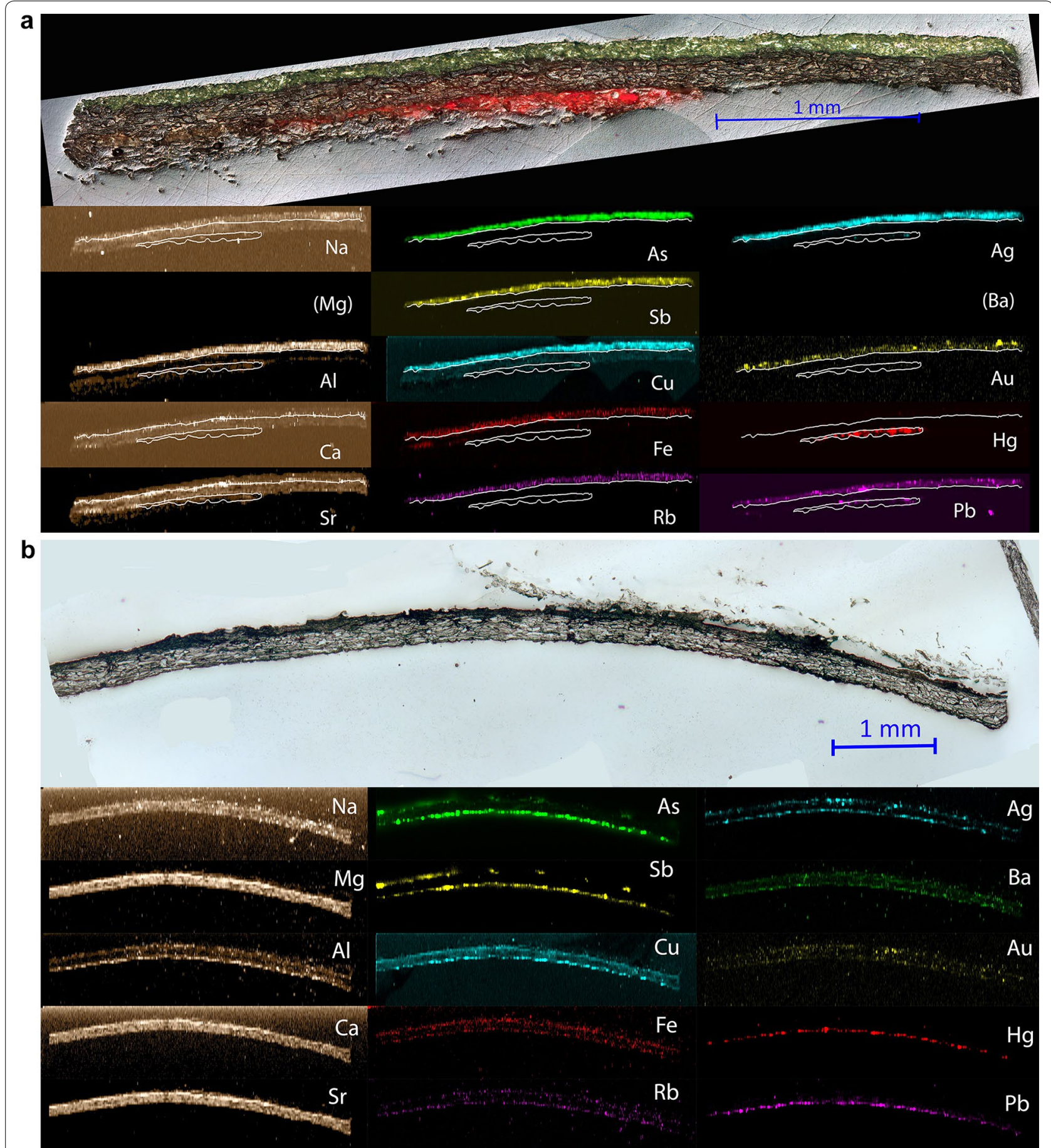

Fig. 3 a KLR-11920 Herlufsholm 768.6. Results of the LA-ICP-MS elemental mapping. Top is an optical photo taken in polarized light. Magnesium and Ba were not detected in this sample. b KLR-11971 Herlufsholm 775.2. Results of the LA-ICP-MS elemental mapping. Top is an optical photo taken in polarized light. c KLR-1 1972 Herlufsholm 186.6. Results of the LA-ICP-MS elemental mapping. Top is an optical photo taken in polarized light. Gold was not detected in this sample. This sample was clearly painted green on both sides. d KLR-12109 Smithsonian QH41.A43 1602. Results of the LA-ICP-MS elemental mapping. Top is an optical photo taken in polarized light. This sample was only painted green on one side 


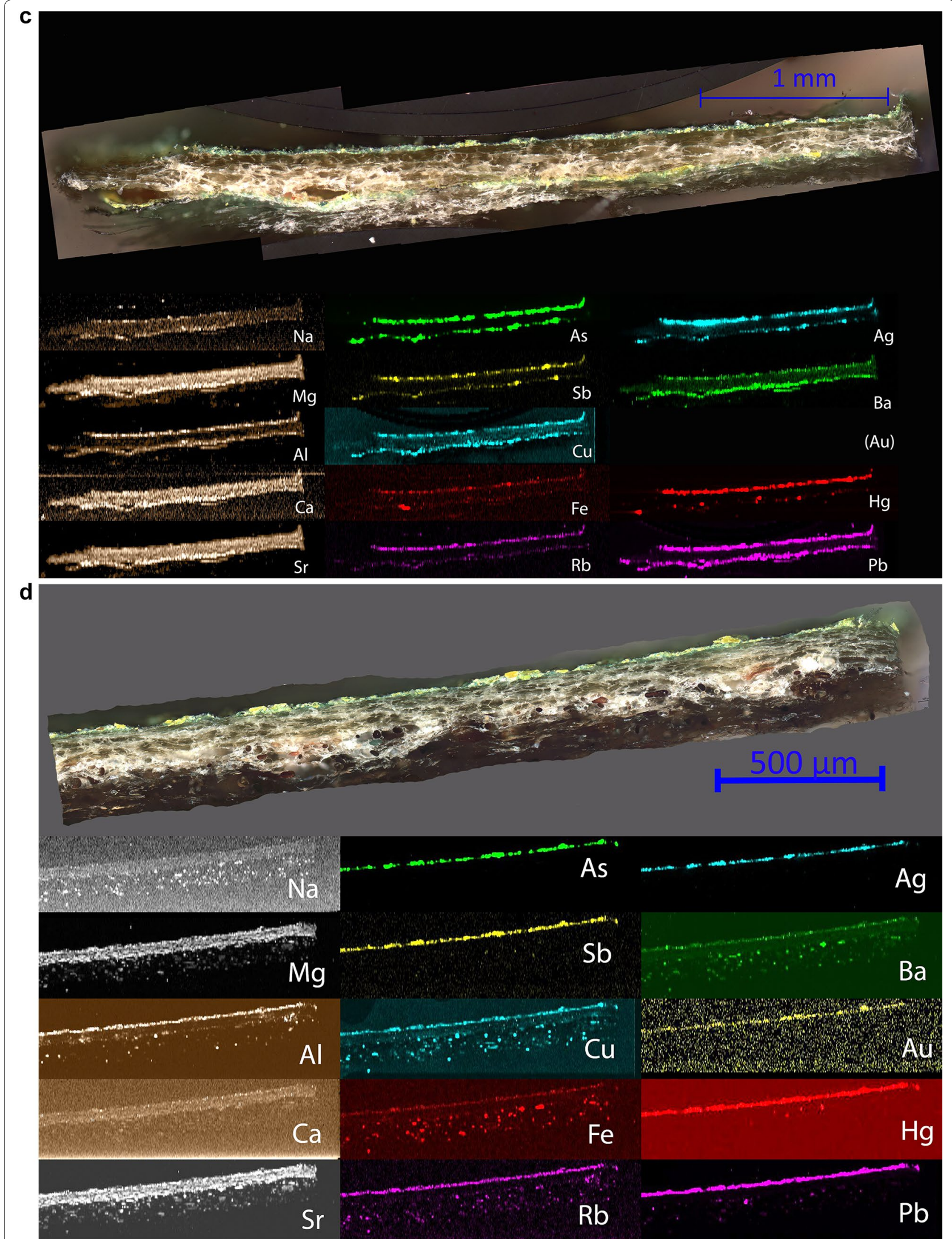

Fig. 3 (continued) 
It should be noted that the LA-ICP-MS results have not been quantified. However, the data clearly displays the spatial distribution of the various elements. The micro photograph of KLR-11920/Herlufsholm 768.6 shows a more than $300 \mu \mathrm{m}$ thick green paint layer on the top side and an orange-red layer on the reverse side (Fig. 3a). It is seen on the elemental plots of Fig. 3a that the orange-red layer contains high amounts of $\mathrm{Hg}$ and small amounts of $\mathrm{Pb}, \mathrm{Al}$, and $\mathrm{Sr}$. The identification based on LA-ICP-MS and on the colour is that the pigment in the red-orange paint is cinnabar $(\mathrm{HgS})$. The green paint contains a variety of possible colorants or toxic elements: $\mathrm{As}, \mathrm{Sb}, \mathrm{Cu}, \mathrm{Fe}$, $\mathrm{Ag}, \mathrm{Au}$, and $\mathrm{Pb}$; as well as other elements: $\mathrm{Rb}, \mathrm{Na}, \mathrm{Al}, \mathrm{Ca}$, and $\mathrm{Sr}$. The parchment wedged between the green paint and the cinnabar, contains $\mathrm{Na}, \mathrm{Ca}$, and $\mathrm{Sr}$. These elements are most likely derived from the preparation of the parchment.

KLR-11971/Herlufsholm 775.2 (Fig. 3b) has a very thin paint layer of approximately $5 \mu \mathrm{m}$ thickness on both sides. The paint on the lower (concave) side is high in $\mathrm{As}, \mathrm{Sb}, \mathrm{Cu}, \mathrm{Rb}, \mathrm{Ag}, \mathrm{Ba}, \mathrm{Hg}$, and $\mathrm{Pb}$, as well as in $\mathrm{Al}$. The very thin paint layer on the upper side is low in As and $\mathrm{Sb} ; \mathrm{Hg}$ and $\mathrm{Pb}$ are not detected by LA-ICP-MS; but the paint layer contains some $\mathrm{Cu}, \mathrm{Fe}, \mathrm{Rb}, \mathrm{Ag}, \mathrm{Ba}$, and $\mathrm{Au}$. In this sample the parchment contains $\mathrm{Na}, \mathrm{Mg}, \mathrm{Al}, \mathrm{Ca}, \mathrm{Sr}$, $\mathrm{Cu}, \mathrm{Ba}$, and $\mathrm{Au}$, which must be said to be a special, even peculiar, inorganic inventory of the parchment itself. An interesting observation on KLR-11871/Herlufsholm 775.2 is that $\mathrm{Hg}$ and $\mathrm{Pb}$ are only detected in the lower (concave) paint layer.

KLR-11972/Herlufsholm 186.6 (Fig. 3c) has a brilliant and distinct green/yellowish layer on the top side, and another similarly coloured layer on the lower side, which, however, is partly embedded in the parchment. The top paint layer contains $\mathrm{As}, \mathrm{Sb}, \mathrm{Cu}, \mathrm{Fe}, \mathrm{Rb}, \mathrm{Ag}, \mathrm{Ba}, \mathrm{Hg}$, and $\mathrm{Pb}$. No Au was detected by LA-ICP-MS in this sample. The lower layer contains similar amounts of $\mathrm{As}, \mathrm{Sb}, \mathrm{Cu}$, and $\mathrm{Pb}$, and only very small amounts of $\mathrm{Fe}, \mathrm{Rb}, \mathrm{Ag}$, and $\mathrm{Hg}$. Barium is higher in the lower layer. The parchment in this sample is high in $\mathrm{Na}, \mathrm{Mg}, \mathrm{Ca}$, and $\mathrm{Sr}$, while $\mathrm{Al}$ is situated equally on both surfaces signifying that $\mathrm{Al}$ originates from clay minerals/dust.

KLR-12109/Smithsonian QH41.A43 1602 (Fig. 3d) has only one distinct and brilliant layer of green paint on the top side. This layer is high in $\mathrm{As}, \mathrm{Sb}, \mathrm{Cu}, \mathrm{Rb}, \mathrm{Ag}, \mathrm{Ba}, \mathrm{Au}, \mathrm{Hg}$, and $\mathrm{Pb}$, while there is no discernible Fe present. The parchment itself contains $\mathrm{Na}, \mathrm{Mg}$, $\mathrm{Ca}$, and $\mathrm{Sr}$, probably stemming from the original medieval curing of the parchment.

\section{$\mu$-X-ray fluorescence}

The elemental compositions measured with $\mu$-XRF are shown in Table 1, which is divided in two parts: in the upper half the elements listed are considered non-colorant and non-toxic, and in the lower half the elements listed are considered potentially colorants and toxic. Even though sulphur is not considered toxic, it is listed with the toxic elements because of the likely association with As when not related to $\mathrm{Hg}$.

The results of the $\mu$-XRF analyses are quite similar in the samples from the four book covers (Table 1). The most abundant elements are $\mathrm{As}, \mathrm{S}, \mathrm{Si}$, and $\mathrm{Ca}$. Lower quantities of $\mathrm{Al}, \mathrm{K}, \mathrm{Ca}, \mathrm{Ti}, \mathrm{Mn}, \mathrm{Fe}, \mathrm{Cu}, \mathrm{Zn}, \mathrm{Pb}, \mathrm{Ba}, \mathrm{Sr}$, $\mathrm{Ag}$, and $\mathrm{Sb}$ are also measured in various proportions. Presence of $\mathrm{Hg}$ is detected in appreciable amounts in KLR-11920, and in lower quantities in KLR-11971 and KLR-11972.

All four compositions are characterised by high amounts of As and $\mathrm{S}$ which suggests the presence of orpiment $\left(\mathrm{As}_{2} \mathrm{~S}_{3}\right)$. The mass ratio between $\mathrm{As}$ and $\mathrm{S}$ in the stoichiometric formula of this mineral is 1.56. In KLR11971, KLR-11971, KLR-11972, and KLR-12109 the As:S mass ratio is $2.33,1.19,2.41$, and 2.40 , respectively, which indicate a surplus of As in all the samples except KLR11971. This is likely caused by the recipe or method of manufacturing of the pigment. The ranges of concentration values of $\mathrm{Si}$ and $\mathrm{Fe}$ are quite narrow, whereas the concentrations of $\mathrm{Ca}, \mathrm{Al}$, and $\mathrm{K}$ are occurring in wider ranges. The LA-ICP-MS analysis showed that both $\mathrm{Al}$ and $\mathrm{Ca}$ are located on the surface layers as well as in the interior of the parchment. Thus, a part of the variation for these two elements, and probably $\mathrm{K}$ as well, could come from a difference in the preparation of the original parchment [11]. The narrow ranges of variation of Si and $\mathrm{Fe}$ could be due to these elements originating from dust grains attached to the surface of the parchment through the centuries. The measurements of $\mathrm{Ti}, \mathrm{Mn}, \mathrm{Cu}, \mathrm{Zn}, \mathrm{Sr}$, $\mathrm{Ag}$, and $\mathrm{Sb}$ show very low concentrations, all below $0.1 \%$. The gold detected by LA-ICP-MS was not identified with the $\mu$-XRF, because of the much lower detection limit of the $\mu$-XRF.

For KLR-11920/Herlufsholm 768.6, the amount of $\mathrm{Ca}$ and $\mathrm{Al}$ is lower than in the other samples however according to the results of the LA-ICP-MS analysis, these elements are also identified in the parchment and could therefore come from a different curing method. The amount of $\mathrm{Hg}$ is the highest measured in this study. Mercury is located in the red cinnabar layer on the concave side of the sample.

Concerning KLR-11971/Herlufsholm 775.2, the concentrations of As and S are the lowest registered in the four samples, which is likely linked to the thinness of the paint layer. The As/S ratio of 1.19 suggest an excess of sulphur in contrast to the other samples. According to the LA-ICP-MS analysis, relative high proportions of $\mathrm{Ca}$ and $\mathrm{Al}$ are located inside the parchment and not in 
Table 1 Results of $\mu$-XRF analysis

\begin{tabular}{|c|c|c|c|c|c|c|c|c|}
\hline \multirow[t]{2}{*}{ Element } & \multicolumn{2}{|l|}{ KLR-11920 } & \multicolumn{2}{|l|}{ KLR-11971 } & \multicolumn{2}{|l|}{ KLR-11972 } & \multicolumn{2}{|l|}{ KLR-12109 } \\
\hline & Concentration, wt $\%$ & RSD, \% & Concentration, wt $\%$ & RSD, \% & Concentration, wt $\%$ & RSD, \% & Concentration, wt $\%$ & RSD, \% \\
\hline Si & 5.64 & 0.1 & 6.36 & 0.1 & 6.73 & 0.1 & 5.34 & 0.1 \\
\hline $\mathrm{Al}$ & 0.144 & 1.9 & 0.625 & 0.5 & 0.439 & 0.6 & 0.492 & 0.5 \\
\hline $\mathrm{Ca}$ & 1.67 & 0.1 & 4.31 & $<0.0$ & 3.06 & $<0.0$ & 2.44 & $<0.0$ \\
\hline K & 1.35 & 0.1 & 0.617 & 0.1 & 0.696 & 0.1 & 1.89 & 0.1 \\
\hline $\mathrm{Ti}$ & 0.055 & 0.3 & 0.071 & 0.3 & 0.042 & 0.4 & 0.023 & 0.6 \\
\hline Sr & 0.011 & 0.3 & 0.026 & 1.3 & 0.028 & 1.8 & 0.002 & 1.5 \\
\hline As & 14.7 & $<0.0$ & 2.66 & $<0.0$ & 8.47 & $<0.0$ & 8.46 & $<0.0$ \\
\hline S & 6.30 & 0.1 & 2.23 & 0.1 & 3.52 & 0.1 & 3.52 & 0.1 \\
\hline $\mathrm{Fe}$ & 0.22 & 0.1 & 0.26 & 0.1 & 0.266 & 0.1 & 0.224 & 0.1 \\
\hline $\mathrm{Mn}$ & 0.013 & 0.4 & 0.014 & 0.5 & 0.014 & 0.5 & 0.011 & 0.6 \\
\hline $\mathrm{Cu}$ & 0.004 & 1.4 & 0.033 & 0.2 & 0.015 & 0.6 & 0.007 & 1.0 \\
\hline $\mathrm{Zn}$ & 0.036 & 0.2 & 0.007 & 0.8 & 0.005 & 1.2 & 0.023 & 0.3 \\
\hline $\mathrm{Pb}$ & 0.010 & 1.0 & 0.008 & 1.0 & 0.008 & 1.2 & 0.005 & 0.7 \\
\hline $\mathrm{Ba}$ & - & - & 0.006 & 1.2 & 0.011 & 0.7 & 0.021 & 0.3 \\
\hline $\mathrm{Rb}$ & 0.001 & 0.3 & 0.002 & 0.3 & 0.002 & 0.2 & 0.002 & 0.2 \\
\hline Hg (counts) & $1.94 \times 10^{7}$ & & $1.37 \times 10^{6}$ & & $1.39 \times 10^{6}$ & & - & \\
\hline Ag (counts) & $4.10 \times 10^{5}$ & & $2.37 \times 10^{4}$ & & $2.02 \times 10^{5}$ & & $3.02 \times 10^{5}$ & \\
\hline Sb (counts) & $2.44 \times 10^{4}$ & & $0.85 \times 10^{4}$ & & $2.54 \times 10^{4}$ & & $3.69 \times 10^{4}$ & \\
\hline
\end{tabular}

Absolute calibration of the concentrations has been performed by the DCCR-method (Direct Calibration from Count Rates) using the standard reference material NIST-2711 for most of the elements and NIST-610 for S. The relative standard deviation (RSD) is listed for each element. No standardisation was done for Hg, Ag, and $\mathrm{Sb}$; instead the observed count rates are listed

the surface layers. The relatively high value of $\mathrm{Cu}$ measured in this sample seems to come from the surface layer, as is also the case for $\mathrm{Hg}$.

In KLR-11972/Herlufsholm 186.6, the As and S concentrations are intermediate between the two previous samples. According to the LA-ICP-MS analysis, Hg and $\mathrm{Pb}$ are located in the surface layer-like in sample KLR-11971.

Concerning KLR-12109/Smithsonian QH41.A43 1602, the amounts of As and S are almost identical to the ones measured in KLR-19972. The major difference between this and the previous sample is the absence of $\mathrm{Hg}$ and the higher amount of $\mathrm{K}$. The excess $\mathrm{K}$ could come from a difference in the type of parchment used, but since $\mathrm{K}$ is not mapped with LA-ICP-MS, this cannot be ascertained with certainty.

\section{X-ray diffraction}

The XRD patterns of the four sample are shown in Fig. 4. The use of the Kapton polyimide foil to seal the samples in the sample holder induced a high background between $5^{\circ}$ and $30^{\circ}$. This background is subtracted from the pattern before processing the data. Because of the thinness of the surface layer on the samples KLR-11971 and
KLR-11972, the intensity of the signal is lower for these two diffractograms and thus, the background relatively higher. XRD patterns highlight the presence of calcite and quartz in addition to orpiment.

The four patterns exhibit the same peaks belonging to three mineralogical phases: orpiment $\left(\mathrm{As}_{2} \mathrm{~S}_{3}\right)$, quartz $\left(\mathrm{SiO}_{2}\right)$, and calcite $\left(\mathrm{CaCO}_{3}\right)$. All the major and minor peaks belonging to orpiment are identified. Thus, the XRD results confirm that the As and S measured in the elemental analysis belong to this phase. The four major peaks attributable to quartz and calcite are also identified. The differences between the four patterns are related to the intensity of the peaks and the shape of the calcite peaks.

The semi-quantitative results calculated using the generalized reference intensity ratio (RIR) method are listed in Table 2. In KLR-11920, KLR-11972, and KLR-12109, orpiment accounts for more than $60 \%$ of the minerals detected, calcite between $10 \%$ and $30 \%$, and quartz between 17 and 27\%. The proportion is different in KLR11971, where orpiment accounts for only 32\%, calcite for $30 \%$, and quartz $38 \%$. It can therefore be said that although the overall recipe for the production of the pigment is similar in all four books, KLR-11971 is slightly different in the mixing ratio. 


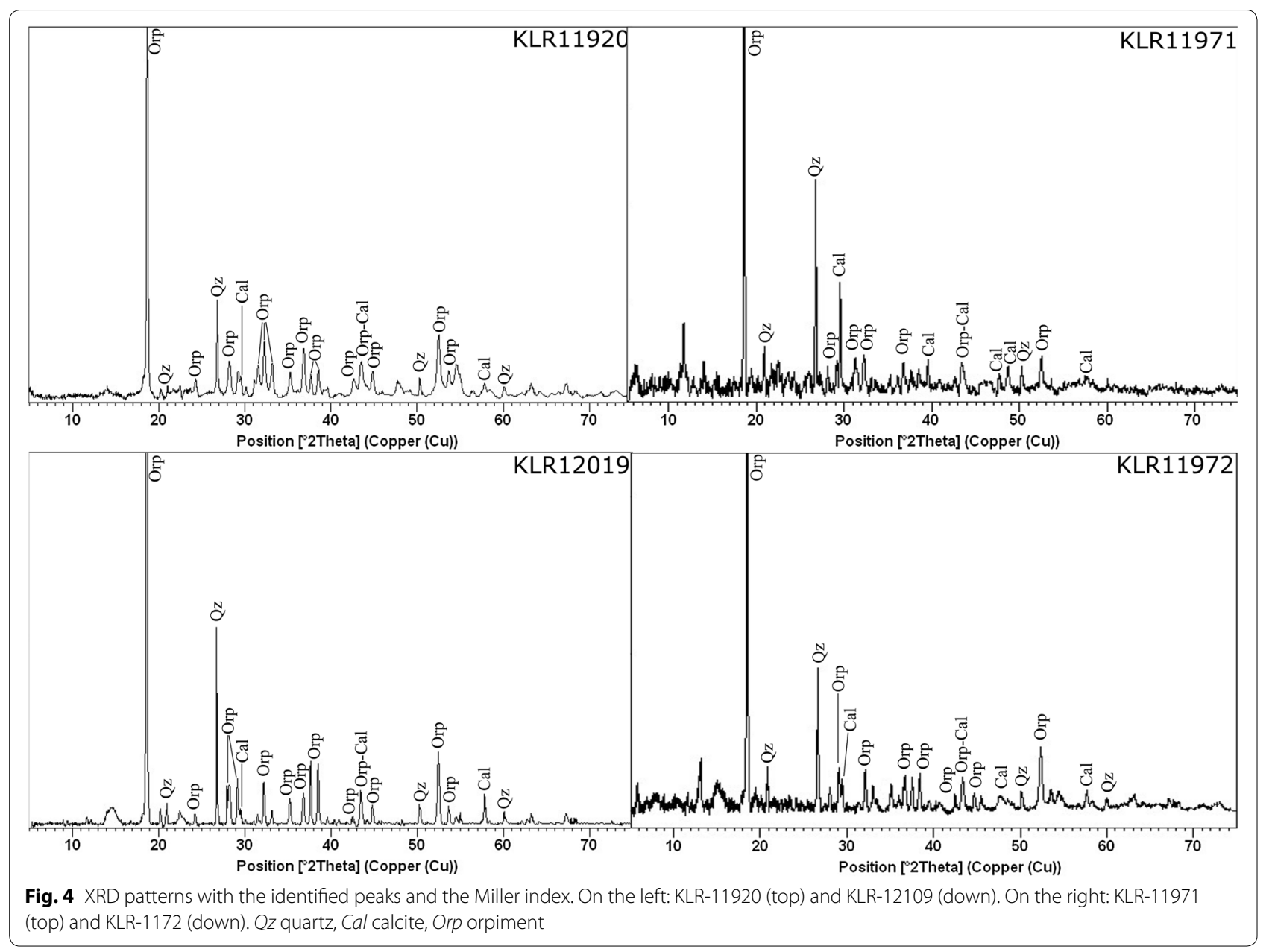

Table 2 RIR semi-quantification of the four XRD patterns

\begin{tabular}{lllll}
\hline Minerals & $\begin{array}{l}\text { KLR- } \\
\mathbf{1 1 9 2 0} \\
(\%)\end{array}$ & $\begin{array}{l}\text { KLR- } \\
\mathbf{1 1 9 7 1} \\
\mathbf{( \% )}\end{array}$ & $\begin{array}{l}\text { KLR- } \\
\mathbf{1 1 9 7 2} \\
\mathbf{( \% )}\end{array}$ & KLR12019 (\%) \\
\hline $\mathrm{SiO}_{2}$-quartz & 20 & 38 & 17 & 27 \\
$\mathrm{As}_{2} \mathrm{~S}_{3}$-orpiment & 69 & 32 & 75 & 61 \\
$\mathrm{CaCO}_{3}$-calcite & 11 & 30 & 8 & 12 \\
\hline
\end{tabular}

\section{Raman spectroscopy}

For each book, the $\mu$-Raman analysis performed on the green layer have been focused on the yellow minerals and on the green phases (Fig. 5). The spectra were recorded between 100 and $1700 / \mathrm{cm}$ but the ones from the yellow minerals are focused on the region $100-450 / \mathrm{cm}$ where the peaks are located.

The positions and the vibrational assignments of the identified bands are listed in Table 3 and the spectra taken is shown in Fig. 5. In the analysis performed on the yellow minerals, seven bands characteristic of orpiment are detected at $\sim 132,153,199,290,307,350$, and $382 / \mathrm{cm}$. The signal from the orpiment is very clear and even the weak intensity bands are displayed. These results combined with the XRD identification confirms that the yellow minerals observed in the micro-photographs are indeed orpiment in all four cases. The spectra produced by the analysis performed on the green phases (Fig. 5b) exhibit the three characteristic bands belonging of indigo $\left(\mathrm{C}_{16} \mathrm{H}_{10} \mathrm{~N}_{2} \mathrm{O}_{2}\right)$ located at $\sim 546,600$, and $1584 / \mathrm{cm}$. In KLR-11920 there is also seen the characteristic lines of orpiment along with indigo, so here a small grain of orpiment was also hit by the laser beam. As an extra confirmation, a scraping from the surficial layer of KLR-11920 was subjected to MS, which showed the presence of protonated indigo (see Fig. 6).

The intensity of the Raman signal seems to be correlated with the thickness of the paint layer, but the bands are still displayed even for sample KLR-11971, which has the thinnest paint layer. The reference Raman spectra of the indigo is characterised by the presence 

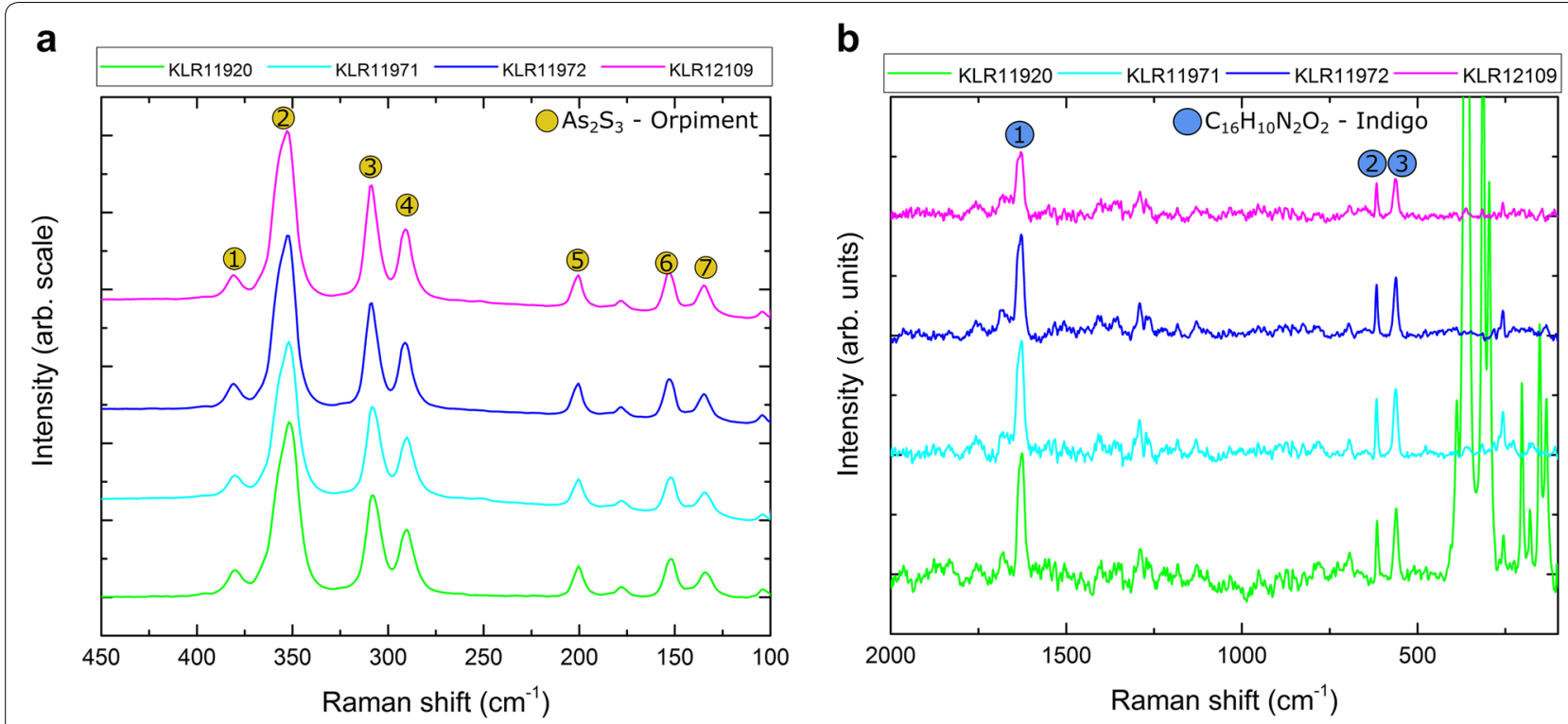

Fig. 5 a Raman spectra focused on the large yellow crystals on the samples from the four books in the range 450-100/cm, showing the characteristic lines of orpiment with yellow circles; $\mathbf{b}$ Raman spectra focused on the green/blue matrix in the range 2000-100/cm, the blue circles show the positions of the characteristic lines of indigo. For sample KLR-11920/Herlufsholm 768.6 is also seen orpiment besides indigo

Table 3 Raman wave numbers of the orpiment identified in the four samples

\begin{tabular}{ll}
\hline Raman $\left(\mathbf{c m}^{-\mathbf{1}}\right)$ & Vibrational assignment \\
\hline Orpiment & \\
$7-137(\mathrm{w})$ & $\mathrm{v} 4$ \\
$6-155(\mathrm{~m})$ & $\delta($ skel $)$ \\
$5-199(\mathrm{w})$ & $\mathrm{v}_{\mathrm{s}}$ (As-S-As) \\
$4-290(\mathrm{~m})$ & $\mathrm{v}_{\mathrm{s}} \mathrm{AsS}_{3 / 2}$ \\
$3-307(\mathrm{~s})$ & $\mathrm{v}_{\mathrm{a}} \mathrm{AsS}_{3 / 2}$ \\
$2-350(\mathrm{vs})$ & $\mathrm{v}_{\mathrm{a}} \mathrm{AsS}_{3 / 2}$ \\
$1-382(\mathrm{w})$ & $\mathrm{v}_{\mathrm{a}}(\mathrm{As}-\mathrm{S}-\mathrm{As})$ \\
Indigo & \\
$3-546(\mathrm{~m})$ & $\delta(\mathrm{C}=\mathrm{C}-\mathrm{CO}-\mathrm{C})$ \\
$2-600(\mathrm{mw})$ & $\delta(\mathrm{C}=\mathrm{O}), \delta(\mathrm{CNHC})$ \\
$1-1584(\mathrm{~s})$ & $\mathrm{v}(\mathrm{C}=\mathrm{C}), \mathrm{v}(\mathrm{C}=\mathrm{O})$ \\
\hline
\end{tabular}

The vibrational assignments are from Burgio [16], Ogalde et al. [17] for the orpiment; and from Karapanayiotis et al. [18]; Baran et al. [19] for the indigo. Band intensity: $w$ weak, $m$ medium, $s$ strong, vs very strong

of several weaker intensity bands, but they are usually not displayed in the analyses of green pigment made of orpiment and indigo [12-14].

\section{Mass spectrometry results}

A sample scraped of the surface of KLR-11920/Herlufsholm 768.6 has been analysed with mass spectrometry. The structure of the indigo molecule contains two internal hydrogen bonds and thus can be protonated more easily than deprotonated [15]. The $\mathrm{m} / z$ ratio of the protonated indigo $\left(\mathrm{C}_{16} \mathrm{H}_{11} \mathrm{~N}_{2} \mathrm{O}_{2}\right)$ is 263.08 . The mass spectrum of the sample KLR-11920 is displayed in the Fig. 6 . The peak at 263.08 confirms the identification of indigo made from the Raman spectra.

\section{Air samples}

All personal exposure and ambient air sampling results for arsenic and arsine were reported as below the limit of detection for the analysis methods used. The detection limit for the sampling method was $0.1 \mu \mathrm{g}$ for total arsenic, and $0.01 \mu \mathrm{g}$ for arsine. The resulting 8-h TWA exposure calculation for the Smithsonian Library staffer monitored was $<0.13 \mu \mathrm{g} / \mathrm{m}^{3}$ for total arsenic and $<0.064 \mathrm{ppb}$ for arsine, which is significantly below both the OSHA PEL and the action level, and the ACGIH and NIOSH recommended limits.

\section{Wipe samples}

Three of the four surface wipe samples for arsenic yielded detectable results, ranging from 270 to $5490 \mu \mathrm{g} / \mathrm{m}^{2}$, indicating significant surface contamination. Two of the three samples had sample concentrations exceeding the $387 \mu \mathrm{g} / \mathrm{m}^{2}$ WTC recommended benchmark, indicating a need to develop safe work practices for handling arsenic containing books that also address preventing surface contamination. These two samples came from the blotter papers placed 


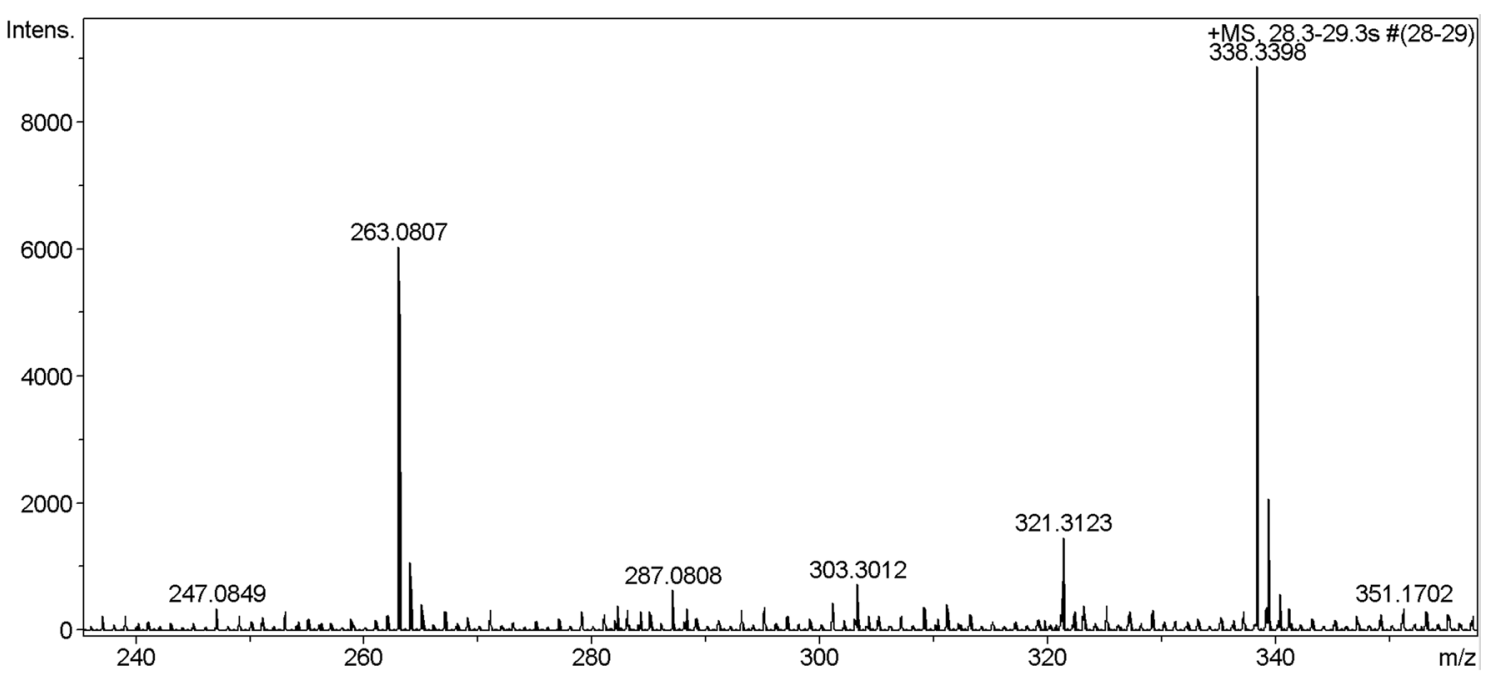

Fig. 6 Mass spectrum of scrapings of the surface layer from the KLR-11920/Herlufsholm 768.6. The mass of protonated indigo is seen

beneath the books during sampling and examination. The wipe sample taken from beneath the KLR12109 , which had visible debris after the procurement of the binding sample, yielded the highest result. The one non-detectable result came from the wipe sample taken of glove surfaces contacted by KLR-12109, while the glove surfaces contacted by the arsenic edge stained book reported the low, but detectable results of $270 \mu \mathrm{g} / \mathrm{m}^{2}$.

\section{Discussion}

\section{Minerals and phases present}

The LA-ICP-MS measurements reveal the detection of several interesting trace elements, such as $\mathrm{Cu}, \mathrm{Sb}$, $\mathrm{Ba}, \mathrm{Au}$ and $\mathrm{Pb}$. Antimony are probably present as trace amounts replacing $\mathrm{As}$ in orpiment, but $\mathrm{Cu}, \mathrm{Ba}, \mathrm{Au}$ and $\mathrm{Pb}$ are not readily explained. However, they are most likely also present as traces in orpiment, because no other mineral phases have been observed by XRD or Raman spectroscopy. An intriguing detail is that $\mathrm{Hg}$ and $\mathrm{Pb}$ are present only in the lower paint layer of KLR-11871/Herlufsholm 775.2, not in the upper. It is therefore probable, that the recipe or provenance of the two paint layers on either side of KLR-11871/Herlufsholm 775.2 are slightly different.

\section{On the nature of the green pigment on the surface layer}

The analysis has proved that the green pigment in the paint layers covering the four books are characterised by a mixture of the yellow pigment orpiment and the blue organic dye indigo. This type of mixture for the colour green is mentioned in the famous manuscript Libro dell'arte written by Cennino Cennini in the first half of the fifteenth century: "A color which is made of orpiment, two parts, and one part indigo, is green; and it is worked up well with clear water. This color is good for painting shields and lances and is also used for painting rooms in secco. It does not want any tempera except size" [20]. There is evidence of orpiment being used as yellow paint as far back as the thirty-first century BCE in Egypt [21], and Cennini's inclusion of a chapter about the pigment in his Libro demonstrates that it never really fell out of use. This chapter includes advice on the preparation of this pigment: Cennini notes that when the orpiment has been ground, it should be mixed with "little of a glass from a broken goblet because the powder of the glass attracts the orpiment to the roughness of the stone" [20]. Allegedly, the glass should help by breaking the fibrous structure of the orpiment and improve the mixing with the blue indigo, although this is not supported by present day experience.

In the paint layers analysed in this paper, the presence of quartz could play the role of broken glass and thus have helped to shred the orpiment mineral fibres. However, it is not clear if the quartz has been added on purpose, or if it was present in the ground orpiment material. This point links to the question of the origin of the orpiment. In nature, orpiment can be the product of either low-temperature hydrothermal veins or a volcanic sublimation product. Regarding the geological environment of the orpiment deposit, it could be associated with quartz, calcite, gypsum $\left(\mathrm{CaSO}_{4} \cdot 2 \mathrm{H}_{2} \mathrm{O}\right)$, baryte $\left(\mathrm{BaSO}_{4}\right)$, or stibnite $\left(\mathrm{Sb}_{2} \mathrm{~S}_{3}\right)$ [22]. However, because of the difficulties met by the craftsmen to grind the orpiment crystal, a synthetic version was later developed. Even though several manuscripts mention orpiment as an "artificial" pigment since the fifteenth century, the first precise 
reference related to a sublimation process is dated to the second half of the eighteenth century. This sublimation could have been done either with natural orpiment or by sublimation of a mixture of sulphur and arsenic trioxide $\left(\mathrm{As}_{2} \mathrm{O}_{3}\right)$ [23]. According to the XRD results, the presence of calcite speaks in favour of a natural origin of the orpiment minerals. Therefore, the quartz could also be coming from the same natural source. The absence of arsenolite $\left(\mathrm{As}_{4} \mathrm{O}_{6}\right)$ in the XRD patterns constitutes another piece of evidence that supports the hypothesis of a natural origin mineral [23], because arsenolite often contaminates synthetic orpiment. However, it must be stressed that we cannot be completely sure of the origin of the orpiment.

The indigo dye is usually described as a dye extracted from the leaves of trees belonging to the Indigofera species. However, other species form similar blue colorants such as Isatis tinctoria or Polygonum tinctorium. Indigo was used in Egypt, China, and India, with the first known occurrence at $6000 \mathrm{BCE}$ in Catal Huyuk, Turkey [24]. Indigo is also known in Greek and Roman antiquity, probably transferred there from Egypt. During the medieval period, tincture from Isatis tinctoria is mentioned in the Capitulare de villis (Carolingian regulation text from the late seventeenth century) and evidence of its use as a fabric dye has been found at a tenth century Anglo-Scandinavian archaeological site in York [25]. Indian indigo became important trading merchandise in Europe with the intensification of the Indian trade and prevailed over the local species based blue pigments from the seventeenth century [26].

The mixture of orpiment and indigo leading to the formation of green colorant is sometimes called "Vergaut" $[27,28]$. Several examples of the use of this pigment in paintings have been found in the Indian and Islamic regions from the tenth to the sixteenth century [12, 29, 30]. In Europe, the mixture has been found in Byzantine manuscript paintings from late antiquity to early medieval times; an early example is a sixth century manuscript that is stored in the Austrian National Library [14]. Occurrences have been also found in English medieval manuscripts from the eighteenth to the eleventh centuries such as the Lindisfarne Gospels [31], and in the famous Irish Book of Kells dated around 800 CE [13]. Pietro Baraldi et al. even speculate that, given the frequent appearance of vergaut in manuscripts dating to before 1000, it was one of the more common pigments used across book production at the time [32]. However, as far as we know this is the first time this pigment has been tested for and subsequently found on the bindings of books.

\section{When and where were the green paint applied?}

The various chemical analysis undertaken on the four samples investigated in this work show that the compositions of the colorants are very similar. The analytical results taken together the samples KLR-11920, KLR-11972, and KLR-12109 are very similar, while sample KLR-11971 has a slightly different mixing ratios than the rest. However, the difference between KLR-11971 and the others could be due to the very thin layer of paint which has been applied to this book. Overall, the chemistry is remarkably similar for all four books. While this similarity is striking, it is possible, if not likely, that all four of these books were bound in the same workshop. Pigment recipe manuals, as both manuscripts and later in print, were widespread in Europe at this time, and it was more efficient to follow these recipes rather than try to reinvent a colour formula. Urban scribes and artists were able to purchase raw ingredients from stationers in this period [21], which may account for some of the similarities in the preparation of minerals.

The problem of which binderies worked with the books and applied the toxic paint can perhaps be elucidated by bibliographical observations of the four books. This style of quarter-pigskin binding was common in sixteenth and seventeenth century Germany [33], and numerous examples survive in libraries all over the world. Examples include the 1596 Examen Concilii Tridentini at the Folger Shakespeare Library in Washington DC, USA (BX830 1545.C4 1596 cage), the 1563 Index omnium scriptorvm reverendi patris $d$. Martini Lutheri at the Johns Hopkins Library Special Collections in Baltimore, MD, USA (BR334.Z9 S3 1563R c.1), the 1561 Omnia quae extant in latinum sermonem conversa at the Royal College of Physicians in London, England (D1/27-f-8), and the 1569 Chronicum absolutissimum a Nino Assyriorum rege usque ad tempora Friderici II auctioned by Christie's on 9 June 2015 in London, Indeed, Mirjam M. Foot noted that German eighteenth century binding manuals actually list a costs for green parchment (12 Gr.) and "parchment that had been written on previously" (the cheapest of all parchment varieties, costing between 1 Thaler and $30 \mathrm{Gr}$. per pound) [34]. David Pearson describes how a combination of rising book production, limited supplies of new materials, and various political and religious upheavals led to the widespread practice of using recycled parchment-also known as manuscript waste-in bindings across Europe in the sixteenth and seventeenth centuries [35].

The three Herlufsholm books have been published in Basel (Switzerland) and in Lübeck (Schleswig-Holstein, Germany) respectively. The bookbinders' use of blind-tooled lines, biblical motifs, the palmette patterns and even the Latin sentences/words was widespread in Europe at the time [4]. Tools for rolls and plates were reused, modified and copied-and could easily be brought from one place to another, e.g. by 
traveling bookbinders. Whether a bookbinder connection exists between the two-fairly synchronous-Basel volumes remains to be proven. The fact that at least two of the Herlufsholm books were owned by people from the northern parts of Germany, near the Baltic Sea, only proves that some books from this area would end up in Danish libraries. Due to their binding style and lack of identifiable binders' marks or dates, it is far more difficult to draw a link between the Lübeck and Bologna volumes, beyond the fact that they were both in Germany in the late sixteenth and early seventeenth centuries.

Assuming that the bookbinders applied the green paint, they could have done so independently in their respective workshops. However, it is possible that green pigment recipes have circulated among the craftsmen, and that the necessary raw materials may have been procured from the same sources in the late sixteenth and early seventeenth centuries. It also seems reasonable that a certain fashion for applying green paint to manuscript waste existed at the time, as noted by Foot [34]. In the case of the 1575 book (Basel), the bookbinder has provided the date of the binding (1581). The gap between the 1575 publication date and 1581 makes it clear that the publication year does not always align with the year of the binding. In the intermediate years, this volume may have travelled far. In all three Herlufsholm cases, the application of green pigment would seem to have been part of the final stages of the work done by the bookbinder. This is evidenced by, for example, the exposure of clean manuscript waste where the Smithsonian Libraries book is missing a pigskin corner.

\section{Toxicity of the paint}

The toxicity of orpiment has been well known since ancient times. Due to its toxic nature, the Romans used slaves to extract this mineral from the mines [36]. In his Libro dell'arte, Cennini also warns several times about the toxicity of the orpiment used in yellow pigment, specifically when it is swallowed [20].

When orpiment interacts with water, it leads to the formation of arsine and arsenic acid which are mainly responsible of the toxicity effect. The complications resulting from the ingestion of orpiment can be severe corrosive damages in the digestive system and intravascular haemolysis. The absorption from the skin can also cause systemic toxicity (see [37]).

Even though the analyses of air and wipe samples have been only performed on the book conserved in the Smithsonian Libraries, the high similarity of the chemical and mineralogical composition between the four books lead us to consider that their toxicity is comparable. However, the condition of such a book may also increase its toxicity potential, especially if it has the potential to pose an ingestion hazard through hand and surface contamination or has been exposed to wet or mold-producing conditions.

\section{Implications for libraries holding poisonous books}

Personal exposure and ambient air sampling for arsenic and arsine performed by the Smithsonian Libraries indicate arsenic and arsine inhalation exposures can be controlled for these poisonous books by using a laboratory chemical fume hood. However, surface wipe results showed that contamination of hands or surfaces when handling one of these books or sampling its painted cover remains an arsenic exposure concern, even when a laboratory chemical fume hood is used.

The poisonous books analysed in this work constitute a risk to human health if handled carelessly. The condition of the book and its binding can also contribute to its health risk, as bacterial action can break down the paint and produce arsine, and damaged covers can release particulate matter, contaminating contacted surfaces and hands. It is important to note here, that the KLR12109 book and the Emmerling book are currently considered to be in good condition, with minimal bacterial or fungal action, and little or no physical damage. In addition to their arsenic hazards, these books were also found to contain additional toxins, in particular, lead and mercury, which could also pose additional health risks for those who have these types of materials in their collections. Therefore, special precautions must be taken regarding the handling and the storage of these books.

For both readers and library personnel, the safe handling of these volumes requires wearing laboratory gloves with the volume(s) place on a protected surface (such as a large sheet of VWR Qualitative filter paper 600, which is standard procedure in our lab). Hands should always be washed after handling. The use of respiratory protection with $\mathrm{P} 100$ filters is recommended when a laboratory chemical fume hood is unavailable. The implementation of a handling protocol and a raised level of awareness of the library staff to this issue can reduce the health risks for users and personnel to a satisfactory level.

Concerning the safe storage conditions needed, the books located in University of Southern Denmark have been stored in storage boxes with warning labels which are placed in a fume cabinet, while the book of the Smithsonian Libraries have been stored in in sealed polyester bags placed in custom fabricated storage boxes containing warning labels. This second option is easy to set-up and do not require expensive materials. Another possible way to ensure safe access to the text of these toxic books is through digitization, but that involves significant costs in the form of equipment, personnel, and digital storage. 
The possibilities outlined above imply both ethical and practical concerns, ranging from the principles of research freedom, and access to public documents, to technical, legal and resource issues raised relating to long term preservation and conservation of cultural heritage objects. Nonetheless, the results presented here underline the necessity for curating institutions to assess the risk of hosting these materials in their collections, to identify such volumes and to implement sufficient storage, and health and safety measures accordingly.

\section{Conclusion}

The four volumes dating from the sixteenth to early seventeenth century with original book bindings investigated here all have similar chemical composition; it is therefore likely that the binders of these books referenced the same recipe for the colour pigment. The colour green is made by a mixture of indigo and orpiment mixed with quartz. There are several trace elements embedded in these phases, most likely in the orpiment. The most notable ones are $\mathrm{Sb}, \mathrm{Cu}, \mathrm{Ba}, \mathrm{Au}$, and $\mathrm{Pb}$, which occur in very low concentrations, but the spatial distribution of which are correlated very strongly with the green paint. The books originate from Basel, Lübeck, and Bologna, and their characteristic German binding structure, style, and the similar chemical composition of their green pigments emphasize how closely-knit sixteenth and seventeeth century bookbinding communities were in this region. There is little doubt that the purpose of applying the green paint was to hide the original medieval writing on the parchment waste, that is to enhance the aesthetic look of the book binding in the eyes of the sixteenth and seventeenth century owners or buyers.

The authors hope that the publication of this paper encourages other libraries to undertake chemical testing on suspect volumes if they are able to. In the case that this level of testing is outside the reach of some libraries, this paper can serve to provide suggestions for basic guidelines for the handling of suspect books in order to minimize contamination. Compiling a larger sample size of this style of binding will enable libraries to pool their expertise and resources relating to proper handling and storage, and may also allow book historians to better pinpoint where these binders worked.

\footnotetext{
Abbreviations

ACGIH: American Conference of Governmental Industrial Hygienists; ACGIH TLV: American Conference of Governmental Industrial Hygienists Threshold Limit Value; FWHM: full width at half maximum; ICDD PDF-2: the international Centre for diffraction data, powder diffraction file; ICP-MS: inductively coupled plasma mass spectrometry; LA-ICP-MS: Laser ablation inductively coupled plasma mass spectrometry; MS: mass spectrometry; $\mu$-XRF: micro-X-ray fluorescence spectrometry; NdYAG: neodymium-doped yttrium aluminium garnet ( $\mathrm{Nd}: \mathrm{Y}_{3} \mathrm{Al}_{5} \mathrm{O}_{12}$ ) laser; $\mathrm{NIOSH}$ : National Institute of Occupational Safety
}

and Health; NIOSH REL: National Institute of Occupational Safety and Health Recommended Exposure Limit; OSHA: Occupational Safety and Health Administration; OSHA PEL: Occupational Safety and Health Administration Permissible Exposure Limit; RIR: relative intensity ratio method; TOF: time of flight; TWA: time weighted average; WTC: World Trade Center; XRD: X-ray diffraction; XRF: X-ray fluorescence.

\section{Acknowledgements}

Permissions to sample the books from the University Library of Southern Denmark and the Smithsonian Libraries were kindly given by Bertil Fabricius Dorch and Leslie Overstreet, respectively. Pia Klingenberg Haussmann is thanked for technical help obtaining the MS spectrum. Mogens Kragsig Jensen kindly contributed to the analysis of provenance of the Danish book samples.

\section{Authors' contributions}

Conceived and designed the experiments: KLR. Performed the experiments: $\mathrm{KLR}$, TD, BJ, and KH. Analysed the data: KLR, TD and BJ. Performed the bibliographic research and description of the books: JPH, VHS, AA, GK. Contributed to the interpretation of results and acquisition of references: $K L R, T D, J P H, V H S$, AA, GK, BFD. Wrote the paper, with comments from other participants: KLR, TD, $\mathrm{JPH}$, and AA. All authors read and approved the final manuscript.

\section{Funding}

The present work has not been funded.

Availability of data and materials

The data are available upon request from the authors.

Ethics approval and consent to participate

No ethical issues are involved in this research.

\section{Competing interests}

We confirm that none of the authors have any competing interests in the manuscript.

\section{Author details}

${ }^{1}$ Cultural Heritage and Archaeometric Research Team (CHART), Department of Physics, Chemistry and Pharmacy, University of Southern Denmark, Campusvej 55, 5230 Odense M, Denmark. ${ }^{2}$ University Library of Southern Denmark, Campusvej 55, 5230 Odense M, Denmark. ${ }^{3}$ Newtec Engineering A/S, Stæremosegaardsvej 18, 5230 Odense M, Denmark. ${ }^{4}$ Joseph F. Cullman 3rd Library of Natural History, Smithsonian Libraries, P. O. Box 37012, MRC 154 Washington, DC 20013-7012, USA. ${ }^{5}$ Preservation Services Dept, Smithsonian Libraries, P.O. Box 37012, MRC 806, Washington, DC 20013-7012, USA.

${ }^{6}$ Smithsonian Museum Conservation Institute, 4210 Silver Hill Road, Suitland, MD 20746, USA. 7 Smithsonian Office of Safety, Health, and Environmental Management, Capital Gallery Building 600 Maryland Ave, S.W. Suite 7106, Washington, DC 20024, USA.

Received: 6 June 2019 Accepted: 24 October 2019

Published online: 07 November 2019

\section{References}

1. Rasmussen KL, Holck JP. Hvad bogbindet gemte - Anvendelse af energidispersiv røntgenanalyse på gamle bogbind. In press Aarbøger for Nordisk Oldkyndighed (in Danish); 2019.

2. Holck JP, Rasmussen KL. How we discovered three poisonous books in our university library. The Conversation; 2018 (https://theconversation .com/how-we-discovered-three-poisonous-books-in-our-university-libra ry-98358).

3. Schunke I. Beiträge zum Rollen- und Platteneinband im 16. Jahrhundert. Konrad Haebler zum 80. Geburtstage am 29. Oktober, 1937 gewidmet. Leipzig: Herausgegeben von Ilse Schunke; 1937.

4. Haebler K. Rollen- und Plattenstempel des XVI. Jahrhunderts; 1928/29, Band 1-2. Leipzig 1928-1929.

5. Willgeroth G. Die Mecklenburg-Schwerinschen Pfarren seit dem dreißigjährigen Kriege, Mit Anmerkungen über die früheren Pastoren seit der Reformation. Band 1, Wismar 1924, p. 349. 
6. Schröder MD. Kirchen-Historie des Evangelischen Mecklenburgs vom Jahr 1518. bis 1742. Dritter Theil.1789. Rostock 1789, p. 252.

7. Pettke S. (ed.). Biographisches Lexikon für Mecklenburg. Band 1. Rostock 2005, pp. 189-191.

8. Hedegaard SB, Delbey T, Brøns C, Rasmussen KL. Painting the Palace of Apries II: ancient pigments of the reliefs from the Palace of Apries. Submitted to Heritage Science: Lower Egypt; 2019.

9. Guillong M, Latkoczy C, Seo JH, Günther D, Heinrich CA. Determination of sulfur in fluid inclusions by laser ablation ICP-MS. J Anal At Spectrom. 2008. https://doi.org/10.1039/b807383j.

10. COPC, Maddaloni M. World Trade Center Indoor Environment Assessment: Selecting Contaminants of Potential Concern and Setting HealthBased Benchmarks. COPC1-e-4. 2003.

11. Ryder ML. Parchment-its history, manufacture and composition. J Soc Archiv. 1964. https://doi.org/10.1080/00379816009513778.

12. Clark RJH, Mirabaud S. Identification of the pigments on a sixteenth century Persian book of poetry by Raman microscopy. J Raman Spectrosc. 2006. https://doi.org/10.1002/jrs.1473.

13. Bioletti S, Leahy R, Fields J, Meehan B, Blau W. The examination of the Book of Kells using micro-Raman spectroscopy. J Raman Spectrosc. 2009. https://doi.org/10.1002/jrs.2231.

14. Aceto M, Agostino A, Fenoglio G, Baraldi P, Zannini P, Hofmann C, Gamillscheg E. First analytical evidences of precious colourants on Mediterranean illuminated manuscripts. Spectrochim. Acta, Part A. 2012; https:// doi.org/10.1016/j.saa.2012.04.103.

15. Colombini M, Modugno F. Organic mass spectrometry in art and archaeology. Chichester:Wiley; 2009.

16. Burgio L, Clark RJH. Library of FT-Raman spectra of pigments, minerals, pigment media and varnishes, and supplement to existing library of Raman spectra of pigments with visible excitation. Spectrochim Acta Part A. 2001:57:1491-521.

17. Ogalde JP, Salas CO, Lara N, Leyton P, Paipa C, Campos-Vallette M, Arriaza B. Multi-instrumental identification of orpiment in archaeological mortuary contexts. J Chil Chem Soc. 2014;59(3):2471-3.

18. Karapanayiotis T, Jorge Villar SE, Bowen RD, Edwards HGM. Raman spectroscopic and structural studies of indigo and its four 6,6A-dihalogeno analogues. Analyst. 2004. https://doi.org/10.1039/b401798f.

19. Baran A, Fiedler A, Schulz H, Baranska M. In situ Raman and IR spectroscopic analysis of indigo dye. Anal Methods. 2010. https://doi. org/10.1039/c0ay00311e.

20. Cennini CDA. The Craftsman's handbook: the Italian "Il libro dell'arte". New-York: Dover Publication; 1954.

21. Baker A. Common medieval pigments. Pittsburgh: University of Pittsburgh; The Cochineal; 2004.

22. Radtke AS, Taylor CM, Heropoulos C. Antimony-bearing orpiment, Carlin gold deposit, Nevada. Jour. Research U.S. Geol. Survey. 1973;1;1:85-87.
23. Eastaugh N, Walsh V, Chaplin T, Siddall R. Pigment compendium: a dictionary and optical microscopy of historic pigments. London: Butterworth-Heinemann; 2008.

24. Cumo C. Encyclopedia of cultivated plants: from acacia to zinnia. Santa Barbara: ABC-CLIO; 2013.

25. Padden A, Nikki PJ, Collins MD, Hutson R, Hall AR. Indigo-reducing Clostridium isatidis isolated from a variety of sources, including a 10thcentury viking dye vat. J Archaeol Sci. 2000. https://doi.org/10.1006/ jasc.1999.0524.

26. Schweppe H. Indigo and woad. In: Fitzhugh EH, editor. Artists pigments: a handbook of their history and characteristics. Washington: National Gallery of Art; 1997. p. 81-108.

27. Conservation and Art Materials Encyclopedia Online (CAMEO) http:// cameo.mfa.org. 2006. Accessed 28 Apr 2019.

28. Clement RW. Medieval and Renaissance Book Production; 1997. Library Faculty \& Staff Publications, Paper 10. https://digitalcommons.usu.edu/ lib_pubs/10.

29. Coomaraswamy AK. The technique and theory of Indian painting: technical studies in the field of fine arts. Fogg art museum: Harvard University; 1934

30. Levey M. Medieval Arabic bookmaking and its relation to early chemistry and pharmacology. Trans Am Philos Soc. 1962;52(4):6-7.

31. Brown KL, Clark RJH. The Lindisfarne Gospels and two other 8th century Anglo-Saxon/Insular manuscripts: pigment identification by Raman microscopy. J Raman Spectrosc. 2004. https://doi.org/10.1002/jrs.1110.

32. Baraldi P, Moscardi G, Bensi P, Aceto M, Tassi L. An investigation of the palette and techniques of some high medieval codicies by Raman microscopy. e-Preserv Sci. 2009;6:163-8.

33. Pickwoad N. Bookbindings and the History of the Book. Arhivski Vjesnik Bulletin d'archives. 2016. p. 157-176.

34. Foot MM. Bookbinders at work: their roles and methods. London: The British Library; 2006.

35. Pearson D. Books as history: the importance of books beyond their texts. London: The British Library; 2008.

36. Ball P. Bright earth: art and the invention of color. New-York: Farrar, Straus and Giroux; 2002.

37. Ozakin E, Can R, Kaya F, Acar N, Cevik AA. Arsenic poisoning due to the intake of orpiment. J Clin Toxicol. 2013;176:3. https://doi. org/10.4172/2161-0495.1000176.

\section{Publisher's Note}

Springer Nature remains neutral with regard to jurisdictional claims in published maps and institutional affiliations.

\section{Submit your manuscript to a SpringerOpen ${ }^{\circ}$ journal and benefit from:}

- Convenient online submission

- Rigorous peer review

- Open access: articles freely available online

- High visibility within the field

- Retaining the copyright to your article

Submit your next manuscript at springeropen.com 